\title{
Seasonal fluctuations in plasma progesterone concentrations in Gentile-di-Puglia and Ile-de-France ewes in southern Italy*
}

\author{
S. Dell'Aquila, B. Varriale $\dagger$, G. Alberico and R. Pierantoni $\dagger$ \\ Istituto Sperimentale per la Zootecnia, 71020 Segezia, Foggia, Italy, and $\uparrow I s t i t u t o$ di Biologia, \\ I Facoltà di Medicina e Chirurgia, Via Costantinopoli 16, 80138 Napoli, Italy
}

\begin{abstract}
Summary. Ile-de-France ewes had high plasma progesterone concentrations during early summer-late winter. Gentile-di-Puglia ewes had high progesterone values during the winter-spring-summer period but during autumn progesterone values were very low and oestrous behaviour was not displayed. The comparison with Ile-de-France ewes indicates that a phase shift occurs in the annual ovarian activity in ewes of the Gentile-di-Puglia breed.
\end{abstract}

Keywords: season; progesterone; photoperiod; ovarian activity; ewes

\section{Introduction}

Seasonal sexual inactivity in sheep is associated with very low concentrations of gonadal hormones due to a reduced frequency of LH pulses compared to that found during the breeding season (Lincoln \& Short, 1980; Haresign et al., 1983; Karsch et al., 1984; Foster et al., 1986). In ewes, it is generally accepted that breeding season is entrained by photoperiod which times the transitions between the breeding and anoestrous seasons. Therefore, gonadal activity is stimulated by decreasing daylength and is suppressed by increasing daylength (Karsch et al., 1984; Robinson et al., 1985). Photostimulation of LH release, via pineal gland control, occurs when daylength decreases due to a decreased sensitivity to the negative feed-back effects of oestrogen (Karsch et al., 1984; Robinson \& Karsch, 1987).

However, some breeds of sheep become reproductively active during the longest days (Shafer, 1964; Ammar-Khodja \& Brudieux, 1982). This phenomenon occurs generally for breeds inhabiting low latitudes and it has been argued that the short-day theory may be not generalized or that it is not applicable to all environmental conditions (Ammar-Khodja \& Brudieux, 1982). We have therefore compared annual fluctuations of plasma progesterone concentrations, as a marker of ovarian activity, in ewes of the Ile-de-France and Gentile-di-Puglia breeds in southern Italy.

\section{Materials and Methods}

Animals and experimental design. The experiment was carried out under natural conditions and the selected animals were never exposed to an artificial photoperiod before the experiment. Mature intact ewes of the Ile-deFrance and Gentile-di-Puglia breeds were used: 6 ewes for each breed were grouped separately in a shed where they were exposed to external climatic conditions throughout the experimental period. Hay $(2 \mathrm{~kg} / \mathrm{day} / \mathrm{animal})$, oats ( $\mathrm{kg}$ /day/animal) and water were always available. Ile-de-France ewes were a third generation born in Italy at the latitude of Segezia (Foggia) $\left(41^{\circ} \mathrm{N}\right)$ where the experiment was carried out. The Gentile-di-Puglia breed has been

*Reprint requests to: Dr Riccardo Pierantoni. 
known in Italy since the 15th century and descends from local populations of sheep crossed with Merino rams imported from Spain. Sheep of this breed are especially available in Puglia, Basilicata and Molise, and constitute one of the most important sheep breeds in southern Italy. The experiment began in June 1985. Gentile-di-Puglia ewes were checked every day for oestrus by using colour-marked vasectomized rams, and blood was then sampled on Day +9 from the detected oestrus. In lle-de-France ewes, blood was sampled every 4 days until the detection of the first oestrus, and then as described for Gentile-di-Puglia ewes. A similar experimental design was used during the period in which rams failed to detect oestrus in Gentile-di-Puglia ewes. Blood sampling was not carried out in Ile-de-France ewes which did not display oestrous behaviour at the beginning of 1986, but the experiment was extended until the end of May for Gentile-di-Puglia ewes.

Plasma progesterone assay. Blood was collected from the jugular vein at 09:00 h. Plasma was stored at $-20^{\circ} \mathrm{C}$ before progesterone radioimmunoassay (Dell'Aquila $e t$ al., 1986). Intra- and interassay coefficients of variation were 7 and $9 \%$ respectively. Sensitivity was $60 \mathrm{pg} / \mathrm{ml}$ plasma.

Statistical analysis. The significance of differences was assessed by one-way analysis of variance and by Duncan's test for multigroup comparisons.

\section{Results}

\section{Ile-de-France ewes}

The first oestrus occurred during August. In this period plasma progesterone concentrations (Fig. 1) increased significantly $(P<0.01)$ and lasted until February. In March progesterone values decreased dramatically $(P<0.01)$ and from this month onwards oestrus was no longer detectable. The duration of anoestrus averaged 170 days.

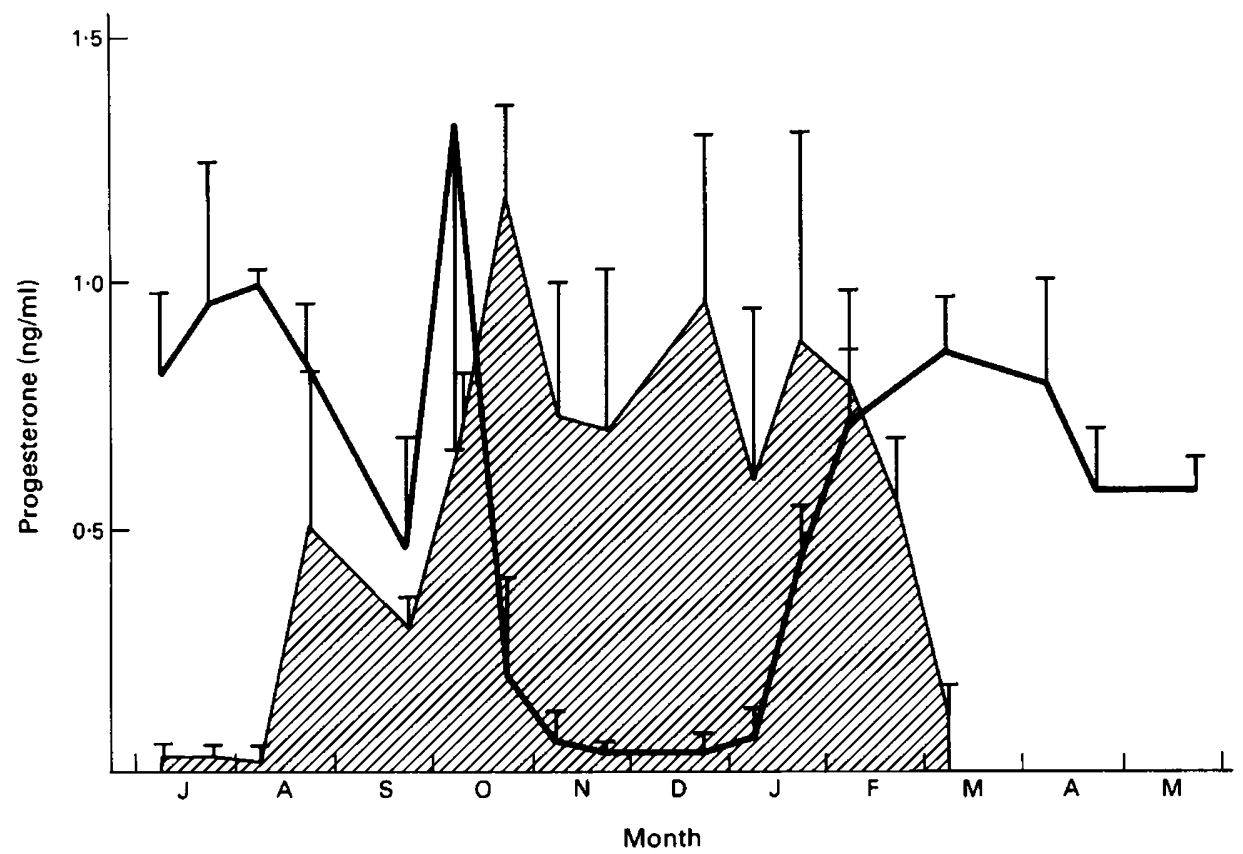

Fig. 1. Seasonal variations in the cyclic luteal activity (measured as plasma progesterone concentrations) in Ile-de-France (hatched area) and Gentile-di-Puglia ewes living in Segezia (Foggia, $41^{\circ} \mathrm{N}$ ). Blood was sampled every 4 days during June until detection of the first oestrus in August (Ile-de-France ewes) and December-January until the onset of the breeding season (Gentile-di-Puglia ewes). Then blood was sampled on Day +9 from the detected oestrus. Values are expressed as means \pm s.d. and are grouped in the first and second halves of each month. 
Gentile-di-Puglia ewes

These ewes (Fig. 1) had high plasma progesterone concentrations from July until the beginning of October. They then decreased to remain at low levels until the beginning of January $(P<0 \cdot 01)$. The duration of anoestrus averaged 120 days.

\section{Discussion}

The present results show that the detection of high plasma progesterone concentration reflects cyclic luteal activity in Ile-de-France ewes that circumscribes a breeding season in general agreement with that reported previously at Nouzilly $\left(47^{\circ} \mathrm{N}\right.$ ) (Thimonier \& Mauléon, 1969; Montgomery et al., 1985, 1987). This experimental design is therefore a good means of assessing fluctuations in ovarian activity and ewes of the Ile-de-France breed in Italy are clearly sexually stimulated as daylength is decreasing, as generally accepted for sheep kept under artificial photoperiod in the laboratory (Karsch et al., 1984; Pelletier, 1986).

The hormonal changes and duration of the oestrous cycle in Gentile-di-Puglia ewes have been reported by Dell'Aquila et al. (1986). In this study, the progesterone values accord well with those measured in the mid-luteal phase by Dell'Aquila et al. (1986). The timing of sexual quiescence in ewes (autumn-early winter) is parallel to that found in males (Dell'Aquila et al., 1985). Therefore, in sheep of the Gentile-di-Puglia breed, the gonads show reduced activity when there is a period of decreasing, rather than increasing, daylength. The comparisons with a third generation Ile-deFrance ewes, examined in the same conditions, may provide support for genotypic influences and argue against the hypothesis related to a phase-shift dependent on environment (Ammar-Khodja \& Brudieux, 1982).

It is hard to envisage, at present, which kinds of environmental cues may regulate the breeding season in sheep such as those of the Gentile-di-Puglia breed which are characterized by reproductive activity during the longest days (Hafez, 1954; Shafer, 1964; Ammar-Khodja \& Brudieux, 1982).

This research was supported by the Italian Ministry of Education (40\% and $60 \%$ grants) and by the Italian Ministry of Agriculture (40\% grant).

\section{References}

Ammar-Khodja, F. \& Brudieux, R. (1982) Seasonal variations in cyclic luteal ovarian activity in the Tadmit ewe in Algeria. J. Reprod. Fert. 65, 305-311.

Dell'Aquila, S., Crasto, A., Alberico, G., Varriale, B., Pelosi, A. \& Pierantoni, R. (1985) Seasonal plasma profiles of testosterone and androstenedione in the Gentile di Puglia ram in southern Italy. J. Endocrinol. Invest. 8, 263-264.

Dell'Aquila, S., Varriale, B., Alberico, G., Crasto, A., Pelosi, A. \& Pierantoni, R. (1986) Plasma sex hormone profile in Gentile-di-Puglia ewes during the estrus cycle. J. Endocrinol. Invest. 9, 83-85.

Foster, D.L., Karsch, F.J., Olster, D.H., Ryan, K.D. \& Yellon, S.M. (1986) Determinants of puberty in a seasonal breeder. Recent Prog. Horm. Res. 42, 331-384.

Hafez, E.S.E. (1954) Oestrus activity in Fat-tailed sheep during the longest day. Experientia 10, 338-340.

Haresign, W., Foxcroft, G.R. \& Lamming, G.E. (1983) Control of ovulation in farm animals. J. Reprod. Fert. 69, 383-395.

Karsch, F.J., Bittman, E.L., Foster, D.L., Goodman,
R.L., Legan, S.J. \& Robinson, J.E. (1984) Neuroendocrine basis of seasonal reproduction. Recent Prog. Horm. Res. 40, 185-232.

Lincoln, G.A. \& Short, R.V. (1980) Seasonal breeding: nature's contraceptive. Recent Prog. Horm. Res. 36, $1-52$.

Montgomery, G.W., Martin, G.B. \& Pelletier, J. (1985) Changes in pulsatile LH secretion after ovariectomy in Ile-de-France ewes in two season. J. Reprod. Fert. 73, $173-183$.

Montgomery, G.W., Martin, G.B., Blanc, M.R. \& Pelletier, J. (1987) Season influences FSH concentration in ovariectomized Ile-de-France ewes. $J$. Reprod. Fert. 80, 271-277.

Pelletier, J. (1986) Contribution of increasing and decreasing daylength to the photoperiodic control of LH secretion in Ile-de-France ram. $J$. Reprod. Fert. 77, 505-512.

Robinson, J.E. \& Karsch, F.J. (1987) Photoperiodic history and changing melatonin pattern can determine the neuroendocrine response of the ewe to daylength. J. Reprod. Fert. 80, 159-165. 
Robinson, J.E., Wayne, N.L. \& Karsch, F.J. (1985) Refractoriness to inhibitory daylengths initiates the breeding season of the Suffolk ewe. Biol. Reprod. 32, 1024-1030.

Shafer, H. (1964) The dependence of fertility on environment in sheep under natural condition of management. Z. Tierzucht. Zucht. Biol. 80, 97-129.
Thimonier, J. \& Mauléon, P. (1969) Variations saisoniers du comportement d'oestrus et des activites ovarienne et hypophysaire chez les ovins. Annls Biol. anim. Biochim. Biophys. 9, 233-250.

Received 3 December 1987 